\title{
First reliable record of Liparis punctulatus (Scorpaeniformes: Liparidae) in Korea
}

\author{
Gyeong Hyun Park, Jin-Koo Kim* \\ Department of Marine Biology, Pukyong National University, Busan 48513, Korea
}

\begin{abstract}
A single specimen of Liparis punctulatus (30.9 mm standard length) belonging to the family Liparidae, was collected in the waters off Busan on 4 August, 2016. This species is characterized by a single pair of nostrils, unlike other Liparis species. It is distinguished from L. ochotensis by the numbers of dorsal, anal, pectoral fin rays and the location of the gill opening (above the pectoral fin in L. punctulatus vs. extending ventrally in front of the pectoral fin). In the molecular analysis, 514 bp of $16 \mathrm{~S}$ rRNA gene of the specimen in this study were identical to that of $L$. punctulatus from NCBI GenBank (K2P distance $<0.002$ ). This is the first record of the species in Korea based on a voucher specimen, and we follow the Korean name "Kko-ma-kkom-chi" for this species proposed by Myoung et al. and Kim et al.
\end{abstract}

Keywords: Liparis punctulatus, First record, Liparidae, Korea

\section{Introduction}

The Liparidae comprise 56 genera and 493 species, which inhabit shallow water to the deep sea worldwide (Eschmeyer et al., 2020). Six species in genus Liparis have been reported in Korea: Liparis agassizii, Liparis chefuensis, Liparis megacephalus, Liparis ochotensis, Liparis tanakae, and Liparis tessellatus (Ji et al., 2012; MABIK, 2019; Park et al., 2013; Song et al., 2015). The liparid species occur mostly in temperate regions of the North Pacific and Antarctic Oceans but are also found in the Arctic and North Atlantic Oceans (Knudsen et al., 2007). Traits used to identify and classify Liparidae include the number of nostrils, position of the anus, and fin ray counts (Sokolovskii \& Sokolovskaya, 2003).

In August 2016, a Liparidae individual was collected in
Gijang, Busan, southeastern Korea. At first, it was morphological identified as juvenile stage of L. tanakae or L. ochotensis, but when was observed in detail, the size of the gill opening of it was different from them. Morphological identification suggested that it was Liparis punctulatus, which was confirmed by comparing the mtDNA $16 \mathrm{~S}$ rRNA nucleotide sequence. In this study, we report the detailed morphological and molecular characteristics based on a L. punctulatus voucher specimen for the first reliable record in Korea.

\section{Materials and Methods}

\section{Sampling}

On 4 August, 2016, a Liparidae individual was collected in 
about $1 \mathrm{~m}$ depth using with a beach seine, in Gijang, Busan, Korea $\left(35^{\circ} 22^{\prime} 4794^{\prime \prime} \mathrm{N}, 129^{\circ} 22^{\prime} 8325^{\prime \prime} \mathrm{E}\right)$. The specimen was fixed in $15 \%$ formalin after collection and then washed and preserved in 99\% EtOH. It was registered and deposited in the Ichthyology Laboratory collection of Pukyong National University (PKU).

\section{Morphological analysis}

The terms and names of each body part and the three counts used (dorsal, anal, and pectoral fin rays) follow the method of Nakabo \& Kai (2013). The 14 measurements were obtained according to Kido (1988). The morphological characters were observed using a stereo microscope (SZH-16, Olympus, Japan) and measured to $0.1 \mathrm{~mm}$ using a microscope photography device (Active Measure, Fuzhou, China) and Vernier calipers.

\section{Molecular analysis}

Genomic DNA was extracted from the lateral body using Chelex 100 resin (Bio-Rad, Hercules, CA, USA). The extracted genomic DNA was preserved at $5{ }^{\circ} \mathrm{C}$ in a refrigerator until used for polymerase chain reaction (PCR). The primers 16 Sar-5' and 16Sbr-3' (Palumbi, 1996) were used to amplify the mitochondrial DNA (mtDNA) 16S rRNA gene. PCR was performed by adding $3 \mu \mathrm{L}$ genomic DNA to a mixture of $3 \mu \mathrm{L} 10 \times$ PCR buffer, $2.4 \mu \mathrm{L} 2.5 \mathrm{mM}$ dNTP, $1 \mu \mathrm{L}$ forward and reverse primers, $0.2 \mu \mathrm{L}$ Takara Taq polymerase, and $20.4 \mu \mathrm{L}$ distilled water to give a final volume of $30 \mu \mathrm{L}$. Then, PCR was performed using a thermal cycler (MJ mini PCT-1148, Bio-Rad, Hercules, California, USA) with an initial denaturation at $95^{\circ} \mathrm{C}$ for $11 \mathrm{~min} ; 35$
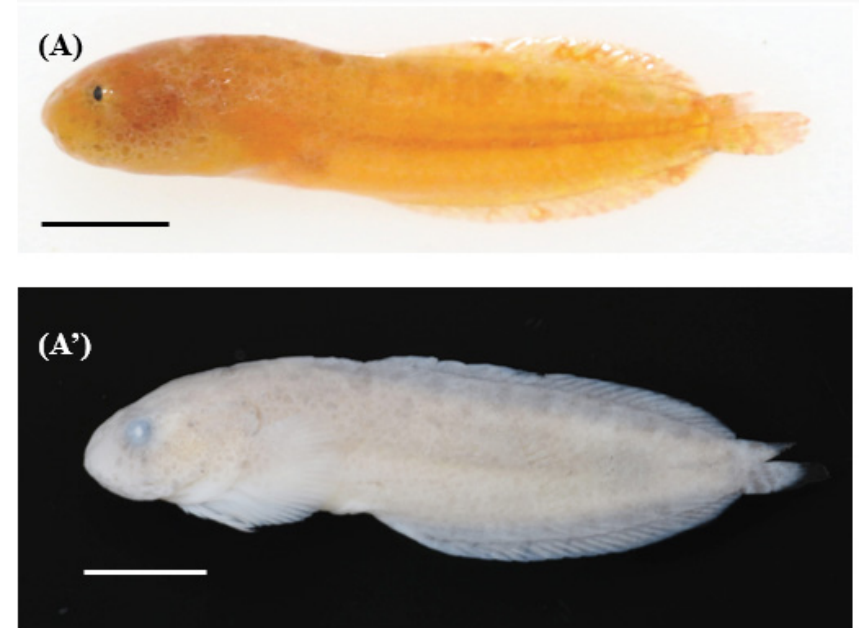

cycles of $94^{\circ} \mathrm{C}$ for $1 \mathrm{~min}, 58^{\circ} \mathrm{C}$ for $1 \mathrm{~min}$, and $72^{\circ} \mathrm{C}$ for $1 \mathrm{~min}$; a final extension at $72{ }^{\circ} \mathrm{C}$ for $5 \mathrm{~min}$; and an infinite hold at $4{ }^{\circ} \mathrm{C}$. The PCR products were sequenced on the ABI PRISM 3730XL Analyzer (96 capillary type) using BigDye ${ }^{\circledR}$ Terminator v3.1 cycle sequencing kits (Applied Biosystems, Foster City, CA, USA). Genetic distances were calculated by the Kimura (1980) 2-parameter model using the program MEGA X (Kumar et al., 2018), and the genetic relationships were analyzed by constructing a neighbor-joining tree using MEGA X (Kumar et al., 2018) with 1,000 bootstrap replications. The sequences of seven Liparidae species obtained from NCBI GenBank were compared: $L$. punctulatus (LC493935), Liparis agassizii (KX156765), Liparis tessellatus (MN880630), Liparis tanakae (LC493937), Liparis ochotensis (MG718032). The 16S rRNA sequences of the specimen and $L$. ochotensis determined in this study were registered at NCBI GenBank (nos. MT579618 and MT579656).

\section{Results}

\section{Liparis punctulatus (Tanaka, 1916) (Figs. 1 and 2) (Korean name: Kko-ma-kkom-chi)}

Careproctus punctulatus Tanaka, 1916: 174 (type locality: Bishamon, Misaki, Kanagawa, Japan).

Liparis punctulatus: Kido, 1988: 168 (Japan); Chernova et al., 2008: 840 (East China Sea and Japan); Nakabo \& Kai, 2013: 1206 (Japan); Parin et al., 2014: 340 (Japan); Myoung et al., 2015: 101 (Korea); Kim et al., 2019: 248 (Korea).
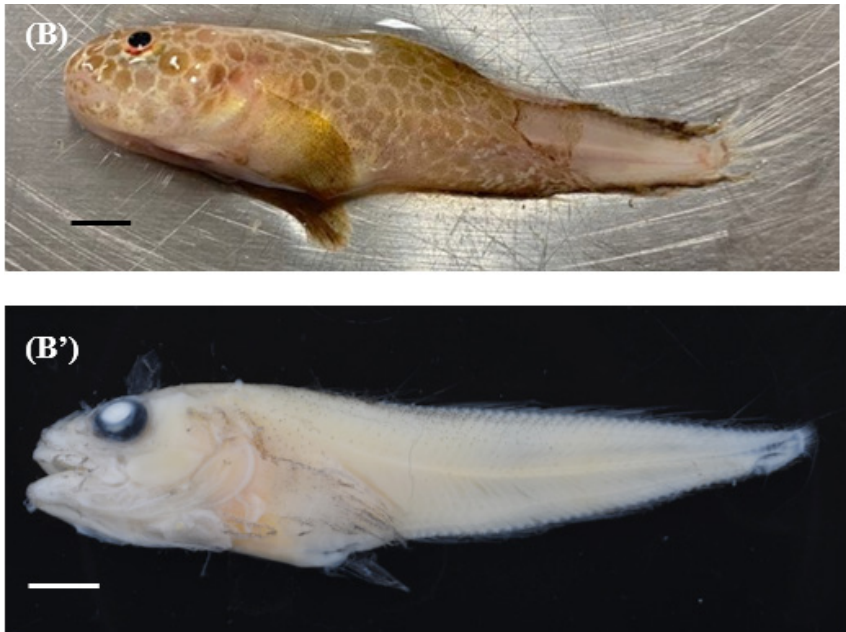

Fig. 1. Photos showing the diagnostic characters distinguishing Liparis punctulatus ( $A, A$ ', immature stage, MABIK PI00049725, $30.9 \mathrm{~mm}$ SL) from Liparis ochotensis (B, B', juvenile stage, PKU 62615, $59.4 \mathrm{~mm} \mathrm{SL).} \mathrm{A} \mathrm{and} \mathrm{B} \mathrm{are} \mathrm{photos} \mathrm{taken} \mathrm{im-}$ mediately after collecting, and $A^{\prime}$ and $B^{\prime}$ are photos taken after preservation in $99 \%$ alcohol. Scale bars indicate $0.5 \mathrm{~cm}$. 
(A)

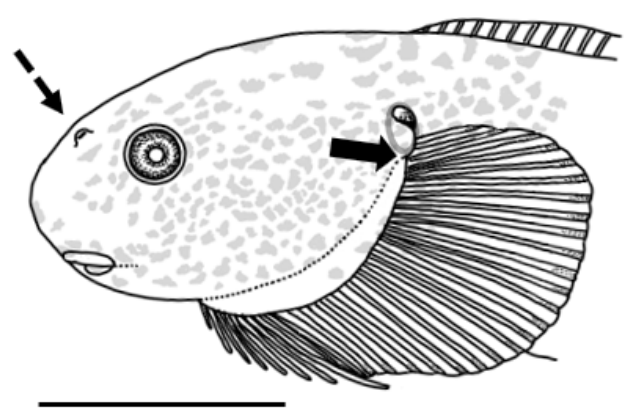

(B)

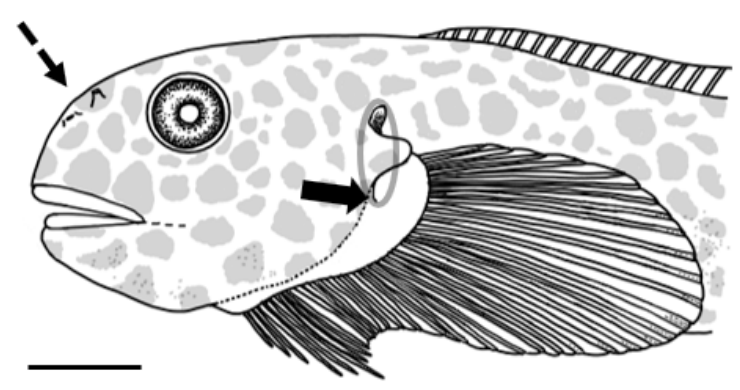

Fig. 2. Sketches of the head and pectoral fin, showing the number of nostrils of Liparis punctulatus (A, MABIK PI00049725) and Liparis ochotensis (B, PKU 62615), the size of the gill opening, and the location of the pectoral fin. The dotted arrows indicate that $L$. punctulatus has a pair of nostrils and $L$. ochotensis has two pairs of nostrils. The ovals represent the gill openings, and the thick arrows indicate the end of the gill openings. Scale bars indicate $0.5 \mathrm{~cm}$.

\section{Material examined}

MABIK PI00049725 (Previously: PKU 62613), one individual, $30.9 \mathrm{~mm}$ SL, coastal water off Gijang, Busan $\left(35^{\circ} 22^{\prime} 4794^{\prime \prime N}\right.$, $129^{\circ} 22^{\prime} 8325^{\prime \prime} \mathrm{E}$ ), August 4, 2016, by beach seine, about 1 meter depth, collector Se Hun Myoung.

\section{Diagnosis}

A pair of nostrils; very small gill opening; the pectoral fin origin at the bottom of the gill opening.

\section{Description}

Counts and measurements are shown in Table 1.

The body shape long oval and flat with a narrow width; the body depth almost constant and decreases at the caudal fin. The head size normal, but eye and mouth small; the nostrils a pair, slightly protruding in short tubular form. The mouth on the ventral of the head; the lower jaw smaller than the upper jaw, and the lower lip is almost inside the upper lip. The gill opening very small. The pectoral fin origin at the bottom of the gill opening and extends to the side of the pelvic fin disk; the pectoral fin oval with a long serrated bottom. The pelvic fin round and large in the form of a large suction disk. The anus located in the middle of the protruding end of the gill opening. The dorsal fin slightly longer than the anal fin, and both extend to the caudal fin. The caudal fin rounded. No scales on the body surface, but small protuberances cover the head and body (Figs. 1A and 2A).

\section{Coloration}

When the specimen was fresh, body yellowish overall with small brown dots over the entire body; no dots on the pectoral fin; horizontal lines of the same color as the dots on the caudal fin; scattered dot pattern on the head.

After the specimen was preserved, body light yellow to white; the head and bases of dorsal and anal fins dark brown.

\section{Molecular analysis}

The sequence of 514 base pairs of the mtDNA 16S rRNA gene (positions 1008-1521) was determined. Comparing the sequence with those of Liparidae registered in NCBI GenBank, the genetic distance was closest to L. punctulatus (LC493935; $d$ $=0.002$ ) and distant from other Liparidae, including L. ochotensis (PKU 62615; $d=0.060$ ), L. ochotensis (MG718032; $d=0.062$ ), L. agassizii (KX156765; $d=0.064), L$. tanakae (LC493937; $d=$ 0.064), L. tessellatus (MN880630; $d=0.065$ ) (Fig. 3).

\section{Distribution}

Western North Pacific; Coastal water off Busan (present study), Japan (Chernova, 2008; Nakabo \& Kai, 2013; Parin et al., 2014), and China (Chernova, 2008).

\section{Remarks}

A Liparidae individual collected in the waters near Gijang, Busan, Korea on August 4, 2016 was identified as L. punctulatus based on morphological and molecular analyses. L. punctulatus is difficult to identify because of its similar body shape and color to those of L. ochotensis. Table 1 shows comparisons of the counts and measurements of the two species. L. punctulatus has small gill opening, and the lower end of gill opening overlaps the second ray of pectoral fin, whereas L. ochotensis has large gill opening that reaches the $18^{\text {th }}$ ray of pectoral fin. In addition, L. punctulatus has one pair of nostrils, whereas L. ochotensis has 
Table 1. Comparison of the counts and measurements of Liparis punctulatus and other species in the genus Liparis

\begin{tabular}{|c|c|c|c|c|c|c|}
\hline \multirow[t]{2}{*}{ Characters } & \multicolumn{3}{|l|}{ Liparis punctulatus } & \multirow{2}{*}{$\begin{array}{l}\text { Liparis ochotensis } \\
\text { Present study }\end{array}$} & \multirow{2}{*}{$\begin{array}{l}\text { Liparis tanakae } \\
\text { Kido (1988) }\end{array}$} & \multirow{2}{*}{$\begin{array}{l}\text { Liparis tessellatus } \\
\text { Kido (1988) }\end{array}$} \\
\hline & Present study & Tanaka (1916) & Kido (1988) & & & \\
\hline Registration number & MABIK PI00049725 & & & PKU 62615 & & \\
\hline Number of specimens & 1 & & & 1 & & \\
\hline Standard length (mm) & 30.9 & - & $21.0-83.0$ & 59.4 & $99.0-474.0$ & $79.0-211.0$ \\
\hline \multicolumn{7}{|l|}{ Counts } \\
\hline Dorsal fin rays & 32 & - & $31-33$ & 44 & $42-44$ & $45-48$ \\
\hline Anal fin rays & 26 & - & $25-28$ & 37 & $34-35$ & $37-40$ \\
\hline Pectoral fin rays & 33 & - & $29-33$ & 40 & $39-45$ & $35-40$ \\
\hline \multicolumn{7}{|l|}{ As $\%$ of standard length } \\
\hline Head length & 30.1 & 26.1 & $24.9-30.2$ & 30.1 & $23.8-29.8$ & $21.7-26.6$ \\
\hline Body depth & 23.0 & 26.7 & $20.4-30.1$ & 19.7 & $21.6-27.8$ & $16.8-26.5$ \\
\hline Head width & 19.1 & - & $19.4-26.1$ & 14.8 & $18.0-25.4$ & $14.2-17.7$ \\
\hline Predorsal fin length & 28.8 & - & $25.7-34.6$ & 36 & $24.5-33.5$ & $25.1-31.9$ \\
\hline \multicolumn{7}{|l|}{ As $\%$ of head length } \\
\hline Snout length & 35.5 & 36.4 & $33.2-39.4$ & 27.9 & $38.3-47.5$ & $33.5-41.1$ \\
\hline Eye diameter & 12.9 & - & $12.9-18.0$ & 17.9 & $9.7-15.5$ & $14.6-25.6$ \\
\hline Interorbital width & 38.7 & - & $36.9-44.1$ & 17.9 & $43.4-54.1$ & $44.5-52.5$ \\
\hline Upper jaw length & 40.9 & - & $34.8-46.6$ & 46.9 & $43.6-57.3$ & $35.5-45.9$ \\
\hline Lower jaw length & 45.2 & - & $32.6-45.9$ & 40.8 & $38.5-50.4$ & $45.9-60.8$ \\
\hline Snout-to-disk length & 50.5 & - & $47.6-71.0$ & 61.5 & $40.8-62.0$ & $53.1-68.0$ \\
\hline Snout-to-anus length & 118.3 & - & $116.3-136.1$ & 133.5 & $120.3-135.8$ & $130.2-174.2$ \\
\hline Disk-to-anus length & 12.9 & - & $12.3-42.8$ & 40.8 & $31.9-55.2$ & $39.1-85.7$ \\
\hline Anus-to-anal fin length & 35.5 & - & $32.3-68.5$ & 30.2 & $14.6-30.0$ & $14.4-35.4$ \\
\hline
\end{tabular}

two pairs (Figs. 1 and 2).

L. tanakae and L. tessellatus, which are frequently caught in the waters near Busan, are distinct from $L$. punctulatus. Unlike $L$. punctulatus, L. tanakae and L. tessellatus have large gill openings that reach the $5^{\text {th }}$ to $12^{\text {th }}$ and $15^{\text {th }}$ to $23^{\text {rd }}$ rays, respectively. Both also have two pairs of nostrils. L. tanakae and L. tessellatus are distinguished from L. punctulatus in that L. tanakae has dark spots or vertical stripes on its bright body, and L. tessellatus has white dots on its dark brown body and more than four-fifths its dorsal fin is fused to its caudal fin. L. chefuensis is similar to $L$. punctulatus because of the yellowish body but is morphologically distinct from L. punctulatus in terms of the presence of two pairs of nostrils and dark brown vertical stripes on the body. The morphological differences are also evident in the counts and measurements shown in Table 1 (Kido, 1988; Nakabo \& Kai, 2013; Song et al., 2015).

Kido (1988) classificated L. ingens as the synonym with L. punctulatus. Then, L. ingens that meaned L. ochotensis in Chyung (1961) also recorded as the synonym with L. punctu- latus in Kido (1988). Based on this, Youn (2002) recorded L. ingens as L. punctulatus, and Nakabo \& Kai (2013) in Japan reported that L. punctulatus lived in Korea.

Park et al. (2018) reported the relations about weight and length for L. punctulatus in Korea. The individuals that Park et al. (2018) evaluated were collected at depths of 50-100 m and measured up to $70 \mathrm{~cm}$ TL (total length), whereas L. punctulatus was recorded as a small fish, with a maximum SL of approximately $8 \mathrm{~cm}$, in shallow water at 0-20 $\mathrm{m}$ depths (Nakabo \& Kai, 2013; Myoung et al., 2015). Therefore, it seems incorrect identification of L. tanakae or L. ochotensis. In this study, $L$. punctulatus and a young L. ochotensis were similar to external morphological characters but had obvious morphological and molecular differences.

No study has evaluated the morphological and molecular characteristics of $L$. punctulatus in Korea based on a voucher specimen. Compared with Kido (1988), Nakabo \& Kai (2013), Tanaka (1916), and, the L. punctulatus individual observed in this study was similar to L. punctulatus in terms of morpholog- 


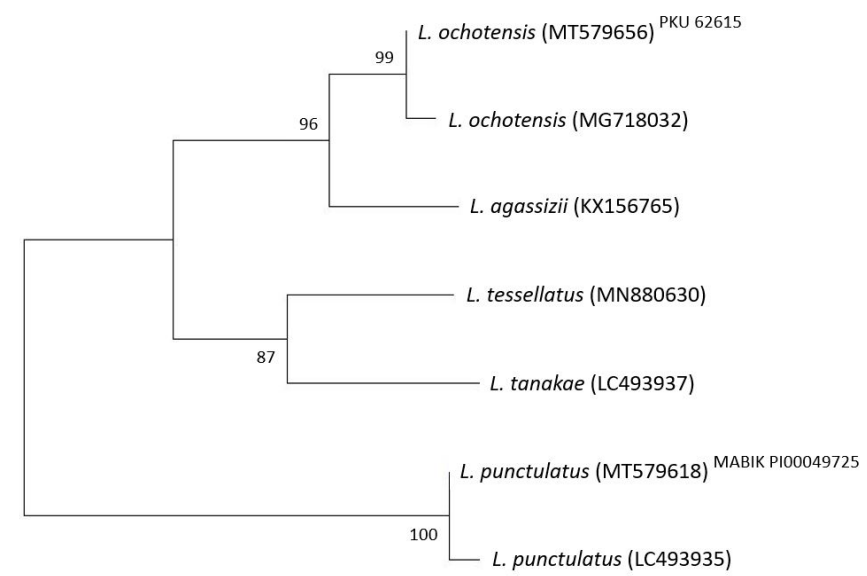

$\underset{0.0050}{\longrightarrow}$

Fig. 3. Neighbor-joining tree constructed using the mtDNA 16S rRNA sequences of Liparis punctulatus (MT579618, LC493935), L. ochotensis (MT579656, MG718032), L. agassizii (KX156765), L. tessellatus (MN880630), L. tanakae (LC493937). The numbers at the branches indicate bootstrap probabilities for 1,000 bootstrap replications. The numbers in parentheses are the NCBI GenBank accession number. The text in superscript represent the voucher specimen numbers. The bar indicates a genetic distance of 0.0050 .

ical characteristics, including the fin ray counts and measurements, and the mtDNA $16 \mathrm{~S}$ rRNA sequence of $L$. punctulatus registered in NCBI GenBank. Therefore, we gave L. punctulatus, which we first identified by morphological and molecular analyses in this study, the Korean name "Kko-ma-kkom-chi" proposed by Myoung et al. (2015) and Kim et al. (2019).

\section{Comparative material examined}

Liparis ochotensis: PKU 62615, one individual, $59.4 \mathrm{~mm} \mathrm{SL}$, sea near Gyeongju ( $\left.35^{\circ} 84^{\prime} 6656^{\prime \prime} \mathrm{N}, 129^{\circ} 57^{\prime} 3773^{\prime \prime E}\right)$, April 30, 2020, by a research vessel from the National Institute of Fisheries Science using a bottom trawl, about 100 meters depth, collector Min Soo Sohn.

\section{Competing interests}

No potential conflict of interest relevant to this article was reported.

\section{Funding sources}

This work was supported by National Marine Biodiversity Insti- tute Research Program (2021M01100).

\section{Acknowledgements}

The authors are sincerely greateful to the reviewers for reviewing with valuable comments. Also, we thank Se Hun Myoung and Min Soo Sohn for help in our sampling. We are thankful to Young Sun Song for help with this paper in analysis guidance.

\section{Availability of data and materials}

Upon reasonable request, the datasets of this study can be available from the corresponding author.

\section{Ethics approval and consent to participate}

This article does not require IRB/IACUC approval because there are no human and animal participants.

\section{ORCID}

Park Gyeong Hyun https://orcid.org/0000-0003-0483-2552 Jin-Koo Kim

https://orcid.org/0000-0002-8499-406X

\section{References}

Chernova NV. Systematics and phylogeny of fish of the genus Liparis (Liparidae, Scorpaeniformes). J Ichthyol. 2008;48:831-52.

Chyung MG. The fishes of Korea. Seoul, Korea: Iljisa Press; 1961. p. 555-6.

Eschmeyer W, Fricke R, van der Laan R. Eschmeyer's catalog of fishes: genera, species, references [Internet]. 2020. [cited 2020 Nov 2]. http://researcharchive.calacademy.org/research/ichthyology/catalog/fishcatmain.asp

Ji HS, Park JH, Ban TW, Kim JK. First record of a snailfish, Careproctus notosaikaiensis (Scorpaeniformes: Liparidae) from Korea. Anim Syst Evol Diversity. 2012;28:308-11.

Kido K. Phylogeny of the family Liparididae, with the taxonomy of the species found around Japan. Sapporo, Japan: Hokkaido University Press; 1988. p. 125-256.

Kim JK, Ryu JH, Ji HS, Park JH, Myoung SH, Song YS, et al. Distribution map of sea fishes in Korean peninsula. Sejong, Korea: Ministry of Oceans and Fisheries; 2019.

Kimura M. A simple method for estimating evolutionary rates of base substitutions through comparative studies of nucleotide sequences. J Mol Evol. 1980;16:111-20.

Knudsen SW, Møller PR, Gravlund P. Phylogeny of the snailfishes (Teleostei: Liparidae) based on molecular and mor- 
phological data. Mol Phylogenet Evol. 2007;44:649-66.

Kumar S, Stecher G, Li M, Knyaz C, Tamura K. MEGA X: molecular evolutionary genetics analysis across computing platforms. Mol Biol Evol. 2018;35:1547-9.

MABIK [Marine Biodiversity Institute of Korea]. National list of marine species. Seocheon, Korea: Namu Press ; 2019. p. 40.

Myoung JG, Ko DB, Kim JS. The illustrated book of Jeju fish. Seoul, Korea: Jisungaa; 2015. p. 101.

Nakabo T, Kai Y. Family Liparidae. In: Nakabo T, editor. Fishes of Japan with pictorial keys to the species. 3rd ed. vol. 2 . Kanagawa, Japan: Tokai University Press; 2013. p. 1205-8 .

Palumbi SR. Nucleic acids II: the polymerase chain reaction. In: Hillis DM, Moritz C, Mable BK, editors. Molecular systematics. Sunderland, MA: Sinauer \& Associates; 1996. p. 205-47.

Parin NV, Evseenko SA, Vasileva ED. Fishes of Russian seas: annotated catalogue. Moscow, Russia: KMK Scientific Press; 2014. p. 340.

Park JH, Ji HS, Yoon BS, Choi YM, Ban TW, Kim JK. First record of a snailfish, Careproctus colletti (Scorpaeniformes: Liparidae) from the East Sea, Korea. Korean J Ichthyol. 2013;25:46-9.

Park JM, Jung HK, Lee CI. Weight-length relations for ten demersal fishes (Actinopterygii) from eastern Korean waters. Acta Ichthyol Piscat. 2018;48:209-11.

Sokolovskii AS, Sokolovskaya TG. Larvae and juveniles of the genus Liparis (Pisces: Liparidae) from the northwestern Sea of Japan. Russ J Mar Biol. 2003;29:305-15.

Song YS, Ban TW, Kim JK. Molecular phylogeny and taxonomic review of the family Liparidae (Scorpaenoidei) from Korea. Korean J Ichthyol. 2015;27:165-82.

Tanaka S. Four new species of Japanese fishes. Zool Mag. 1916;28:26-8.

Youn CH. Fishes of Korea with pictorial key and systematic list. Seoul, Korea: Academy Book Press; 2002. p. 585-6. 